\title{
Investigation of Breast Cancer Cells and Phospholipid Cell Membrane Interactions
}

\author{
Meme Kanseri Hücrelerinin Fosfolipit Hücre Zarı ile \\ Etkileşimlerinin incelenmesi
}

\section{Özgün Araştırma Research Article}

\author{
Ahu Arslan Yıldız $\odot$
}

\begin{abstract}
Objective: Circulating tumor cells have an important role in the pathogenesis of metastasis. Metastasis occurs through few steps including arrival of circulating tumor cells to distant tissue and organs, their adherence to the target tissue, and then formation of a new tumor. To understand the mechanism of this process it is necessary to investigate the interaction of cancer cells with other molecules and cells of the target tissue, and most importantly interaction with lipids forming the cellular membrane.

Methods: To better understand the process of cancer cell adhesion onto lipid membranes and the ionic interactions that are involved in cell adherence, surfaces functionalized with tethered bilayer lipid membrane (tBLM) were utilized in this work as an experimental platform. Either lipid surfaces functionalized with cationic POEPC: PC or anionic POPS: PC fwere examined to observe the ionic interaction of charged phospholipid membrane and MDA-MB231 breast cancer cells.

Results: Adhesions of MDA-MB-231 breast cancer cells and NIH-3T3 mouse fibroblast cells to positively charged POEPC: PC lipid surfaces, and their dissemination was observed during examinations using Surface Plasmon Resonance (SPR) method. The results were further confirmed with cell viability and proliferation studies that shows cationic POEPC: PC lipid surfaces were able to facilitate and increase the cell adhesion.

Conclusion: These results reveal the cationic phospholipid structures favour the enhanced cancer cell adhesion.
\end{abstract}

Keywords: Breast cancer, metastasis mechanism, artificial lipid membranes, cancer cell adhesion

\section{öz}

Amaç: Dolaşımdaki kanser hücrelerinin metastaz oluşmasındaki rolleri önemlidir. Metastaz kanser hücrelerinin diğer organ ve dokulara ulaşması, ve sonrasında hedef dokuya tutunması sonucunda yeni bir tümör oluşumunun başlaması ile gerçekleşir. Bu mekanizmanın çözümlenebilmesi için kanser hücrelerinin hedef dokudaki diğer moleküllerle, hücrelerle ve en önemlisi hücre zarını oluşturan lipitlerle etkileşiminin incelenmesi gerekmektedir.

Yöntem: Bu çalışmada, kanser hücrelerinin fosfolipit hücre zarına tutunma sürecini ve hücre tutunmasına etki eden iyonik etkileşimleri daha iyi anlayabilmek için yüzeye tutturulmuş katmanlı lipit membranlar (tBLM) ile fonksiyonlandırılmış yüzeyler deneysel platform olarak kullanılmıştır. Katyonik POEPC: PC veya anyonik POPS: PC ile fonksiyonlanmış lipit yüzeyler, fosfolipit hücre zarı ve MDA-MB-231 meme kanseri hücreleri arasındaki iyonik etkileşimi gözlemlemek için incelendi.

Bulgular: Yüzey Plazmonu Rezonansı (SPR) ile yapılan incelemelerde MDA-MB-231 meme kanseri hücrelerinin ve NIH-3T3 fare fibroblast hücrelerinin pozitif yüklü POEPC: PC lipit yüzeylere tutunduğu ve yayıldığı gözlemlendi. Bu sonuçlar ayrıca hücre canlılığı ve hücre büyümesi analizleri ile doğrulanarak katyonik POEPC: PC lipit yüzeylerinin hücre tutunması prosesini hızlandırdığı ve artışa neden olur yönde etkilediği gözlemlendi.

Sonuç: Elde edilen sonuçlar katyonik fosfolipit yapının fazla olduğu hücre zarının kanser hücrelerinin tutunmasını kolaylaştırdığını kanıtlamaktadır.

Anahtar kelimeler: Meme kanseri, metastaz mekanizması, yapay lipit membranlar, kanser hücrelerinin tutunması

(C) Telif hakkı TC. Sağlık Bakanlğı izmir Tepecik Eğit. ve Arast. Hastanesi. Logos Tip Yayıncluk tarafindan yayınlanmaktadır.

Bu dergide yayınlanan bütün makaleler Creative Commons Attf-GayriTicari 4.0 Uluslararası Lisansı ile lisanslanmıştr.

(c) Copyright Association of Publication of the T.C. Ministry of Health Izmir Tepecik Education and Research Hospital.

This journal published by Logos Medical Publishing.

Licenced by Creative Commons Attribution-NonCommercial 4.0 International (CC BY-NC 4.0) 


\section{INTRODUCTION}

Cancer is one of the most important cause of death in developed countries, it is not the primary tumor but metastases are fatal most of the time. Circulating tumor cells (CTCS) have an important role in metastatic cascade. CTCs that circulate in blood stream reach to distant organs, and then proceed with new tumor formation after finding a suitable niche. However different types of cancer cells can settle and form metastases at different tissues ${ }^{(1)}$. Cancer cells prefer a suitable microenvironment for settlement and development. This process is directly related with the interaction of the cancer cell surface molecules and surrounding cells such as endothelial cells ${ }^{(2,3)}$. Despite increasing investigation and study of cancer cells, little attention has been paid to the investigation of interactions between cancer cells and surrounding microenvironment.

Mostly cell adhesion occurs based on electrostatic or biorecognition interactions, however cell adhesion studies generally suffer from lack of any suitable experimental platform. There are various surfaces both synthetic and biomimetic, developed and also utilized for cell adhesion, proliferation and differentiation ${ }^{(4)}$. Artificial lipid membranes have received considerable attention by researchers for various biological applications as biosensors and sensor interfaces, drug delivery carriers, imaging agents and biofunctionalized surfaces for living material attachment ${ }^{(4)}$. In this regard, mimicking the real cell microenvironment via lipid membrane model offers the most suitable experimental platform to study cancer cell adhesion. Lipid bilayers offer unique possibilities for controlled functionalization of solid surfaces. Lipid membranes containing zwitterionic properties, that have both positively and negatively charged head groups such as phosphatidylcholine, are prone to fouling and unspecific adsorption of proteins ${ }^{(5,6)}$. Not only the native mimicking behaviour of lipids hence they are already an important component of a cell membrane, but also fluidity and soft nature of lipid membrane system provides the most suitable physiological environment for cell adhesion. Controlled functionalization of surfaces with lipid bilayers is an important step towards the development of bioactive surfaces employed in cellbased studies ${ }^{(7-13)}$.

Herein, a tethered bilayer lipid membrane (tBLM) functionalized platform has been utilized for cancer cell adhesion studies (Figure 1). A comparative study has been provided for two oppositely charged surfaces to show the importance of electrostatic interactions on cancer cell adhesion studies. Adhesion behaviour of MDA-MB-231 breast cancer cells were investigated using Surface Plasmon Resonance (SPR), also NIH-3T3 mouse fibroblast cells were utilized as a control cell line. Besides attachment of cells onto lipid membrane functionalized surfaces, proliferation and toxicity behaviour of the cells were investigated to see the long-term viability of cancer cells at designed microenvironment.

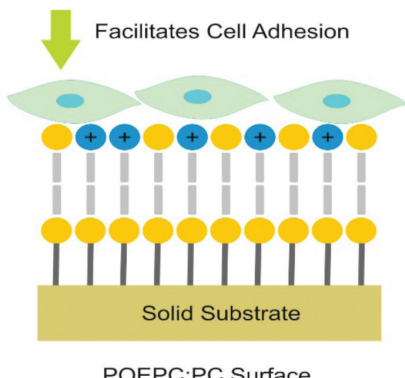

POEPC:PC Surface

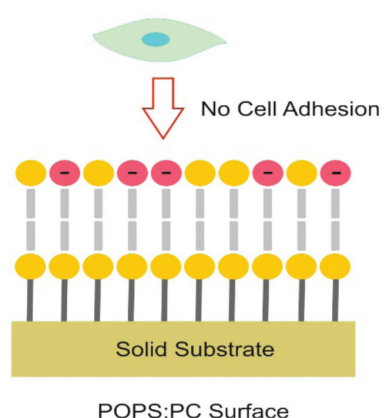

POPS:PC Surface
Figure 1. Schematic representation of selective cell adhesion.

\section{MATERIALS and METHODS}

Surface Preparation and tBLM Formation: Gold slides (Nanodev Scientific, TR) were cleaned using piranha solution ( $3: 1$, conc. $\mathrm{H} 2 \mathrm{SO} 4,30 \% \mathrm{H}_{2} \mathrm{O}_{2}$ ). After washing step, slide surfaces weredried with N2 gas to remove any moisture. Self-assembly of tBLM was performed as described previously ${ }^{(14)}$. Self-assembly of P19 spacer were completed by incubating gold surface with $0.01 \mathrm{mg} / \mathrm{ml}$ peptide solution $(\mathrm{pH}:$ 7.0) followed by activation of the terminal $\mathrm{COOH}$ groups 
by using $0.4 \mathrm{M}$ EDC and $0.1 \mathrm{M}$ NHS for $10 \mathrm{~min}$, then $0.2 \mathrm{mg} / \mathrm{ml}$ DMPE solution (in PBS with $0.1 \%$ TritonX100) was added to the solution, and incubation was completed in $60 \mathrm{~min}$. For the formation of bilayer L- $\alpha$-Phosphatidylcholine (PC), 1-palmitoyl-2-oleoylsn-glycero-3-phospho-L-serine (POPS) and 1-palmitoyl-2-oleoyl-sn-glycero-3-ethylphosphocholine (POEPC) (Avanti Polar Lipids, AL, US) lipid mixtures in corresponding ratios were used. Either $1.0 \mathrm{mg} / \mathrm{ml}$ anionic POPS:PC (1:3) or cationic POEPC:PC (1:3) (15) vesicles were added and incubated for $90 \mathrm{~min}$ for bilayer formation, and $50 \mathrm{~nm}$ vesicles were prepared by extrusion method as described elsewhere ${ }^{(14)}$. After each step, rinsing was performed by using PBS buffer. All steps were carried out at room temperature.

Protein Adsorption onto tBLM Surface: Protein adsorption studies were carried out by using BCA protein kit (Bicinchoninic Acid, Pierce Thermo Fisher Scientific, USA) and BSA (Bovine serum albumin, Sigma Aldrich) were used to analyse the protein adsorption on tBLM surfaces. Standard solutions and corresponding dilution series from 0 to $2000 \mu \mathrm{g} / \mathrm{ml}$ BSA were prepared according to the manual of the BCA kit. For each concentration 3 replicates were used. Then $25 \mu \mathrm{L}$ of each BSA solution was separated to measure the initial solutions. Later, $200 \mu \mathrm{L}$ of each BSA solution was incubated with either POEPC:PC or POPS:PC functionalized surfaces for 2 hours at $37^{\circ} \mathrm{C}$. After incubation period, $25 \mu \mathrm{L}$ of BSA solution were used to measure final protein concentration.

Cell Culture and Cell Viability: MDA MB 231 human breast adenocarcinoma cells (ATCC HTB-26) and NIH 3T3 Mouse fibroblast cells (ATCC CRL-1658) were cultured in high glucose DMEM (GIBCO, ThermoFischer Scientific) containing L-glutamine supplemented with 10\% FBS (GIBCO, ThermoFischer Scientific), 50 units/ $\mathrm{ml}$ penicillin, and 50 units $/ \mathrm{ml}$ streptomycin. Cells were cultured up to $90 \%$ confluency in a humidified environment $\left(5 \% \mathrm{CO}_{2}, 37^{\circ} \mathrm{C}\right)$, and harvested cells were used further for cell adhesion studies.
To investigate the cell proliferation and viability, glass slides were used for microscopy imaging. SLB functionalized, either POPS:PC or POEPC:PC, glass slides were prepared as explained previously ${ }^{(16)}$ and used as a cell adhesion platform. Cells were seeded at SLB functionalized glass slides with starting number of $1 \times 10^{3}$ cells/slide and incubated at 24-well plates for 7 days. Culture medium was replenished every 2 days.

For cell viability experiments, live/dead assay reagents CytoCalcein ${ }^{\text {TM }}$ Green and Propidium lodide (PI) dye (AATBioquest) was used in equal proportions and added into assay buffer solution. Cells were stained with dye solution at $37^{\circ} \mathrm{C}$ for $30 \mathrm{~min}$ and live/ dead analysis was performed using a fluorescence microscope (Zeiss Observer Z1), image analysis and cell counting were done via ImageJ software (NIH). Trypan Blue Assay (Sigma Aldrich Co., USA) and Alamar Blue Assay (Santa Cruz Biotechnology Inc., USA) were performed to quantify the cell proliferation and viability for (1/3/5/7 days) culture.

Cell Adhesion Studies via SPR: Right after tBLM formation on gold slides, freshly harvested MDA MB 231 or NIH 3 T3 cells in culture medium was incubated in the flow cell of SPR setup (Nanodev Scientific, TR). SPR measurement was taken in kinetic mode to observe the cell adhesion behaviour on tBLM functionalized surfaces.

\section{RESULTS}

Cell Interaction with Lipid Bilayer Surface: The fabrication and detailed characterization of tBML surfaces have been described previously ${ }^{(14)}$. Kasemo et al. ${ }^{(15)}$, used the same lipid content for the formation of lipid bilayers, which confirms the formation of oppositely charged bilayers. The lipid bilayer functionalized solid surface acts as an attachment platform for cell adhesion. This work shows the effect of ionic charge of the surface on cell adhesion process. PC is one of the main lipid components of a cell 
a
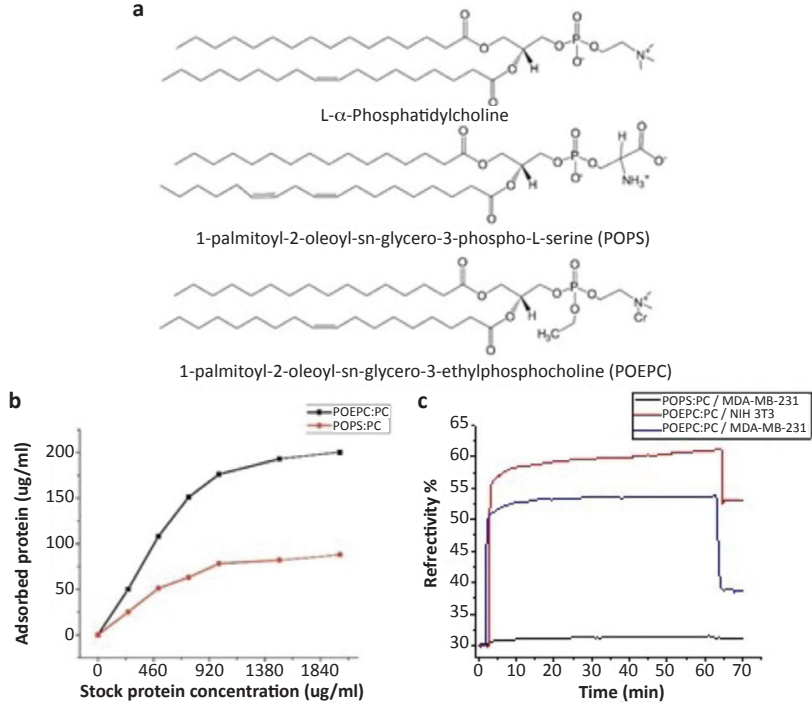

Figure 2: (a) Chemical structures of lipids utilized to functionalize the solid surface, (b) Protein adsorption profiles of negatively charged and positively charged lipid surfaces, (c) SPR kinetic measurements for cell adhesion on to negatively charged and positively charged lipid surfaces for both MDA-MB-231 and NIH 3T3 cell lines.

membrane; therefore PC-based tBLM surfaces were prepared which contain either anionic POPS or cationic POEPC lipids (Fig 2a).
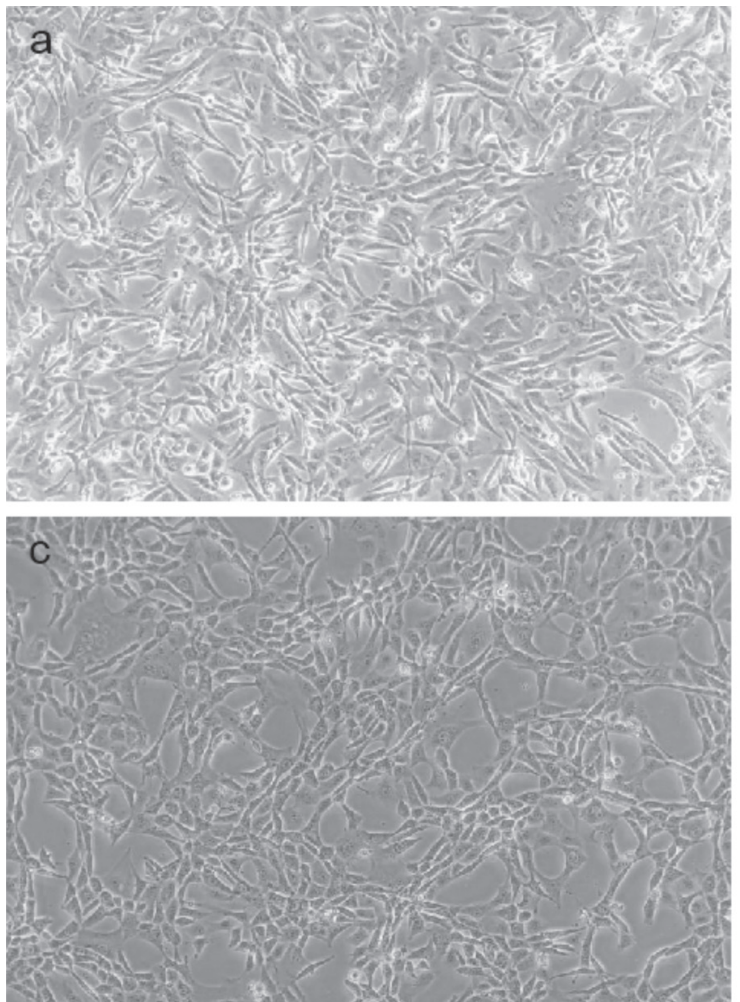

Protein adsorption facilitates the cell adhesion and proliferation. Protein adsorption, hence cell adhesion is directly related with surface interactions, and the major driving forces include surface energy, hydrophobicity and ionic interactions. Here as a first step protein adsorption onto charged tBLM membranes was investigated to estimate the cell adhesion behaviour. BSA is negatively charged at $\mathrm{pH} 7.0$ since its $\mathrm{pl}$ (isoelectric point) is $4.7^{(17)}$. Therefore it mimics the negatively charged membrane surface. Amount of adsorbed proteins on tBLM surface functionalized with positively charged POEPC lipids showed an increase and reached to steady-state (Fig $2 b)$. As shown in the same graph similar behaviour is also observed for positively charged POPS lipids however the amount of adsorbed protein was relatively low compared to POEPC lipid surface.

Later, cell adhesion on a tBLM surface was monitored by SPR in kinetic mode right after tBLM formation. Cell-lipid membrane interaction is a kinetic
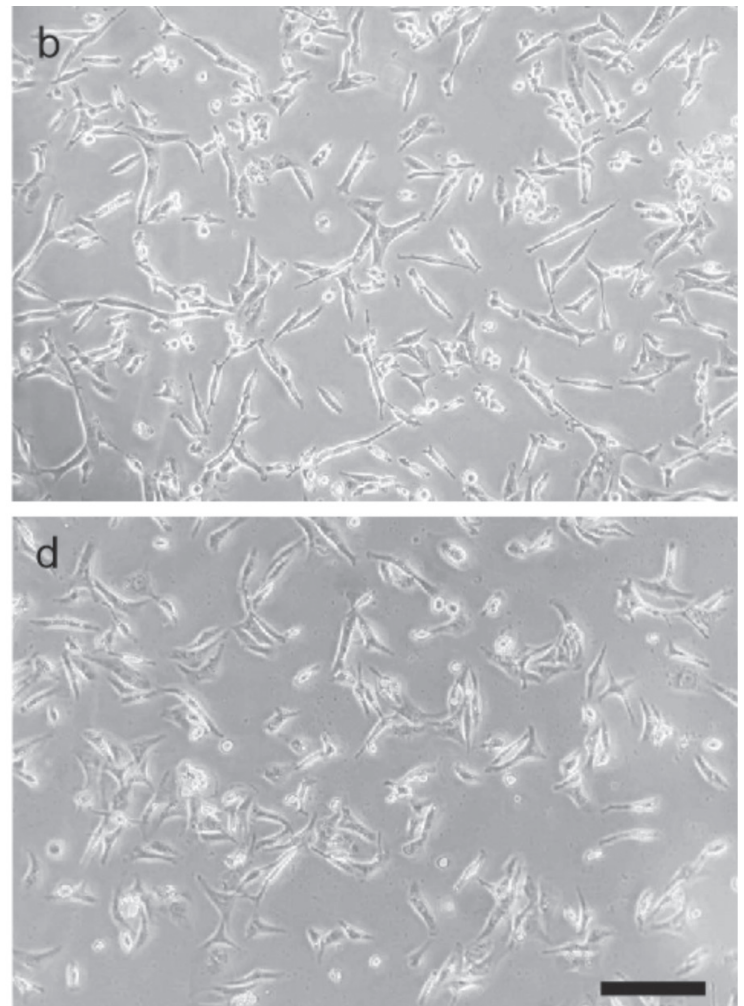

Figure 3. Cell attachment to lipid bilayer via ionic interactions. 48 hour culture of MDA-MB-231 cells on (a) POEPC:PC and (b) POPS:PC functionalized

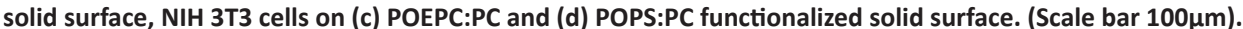



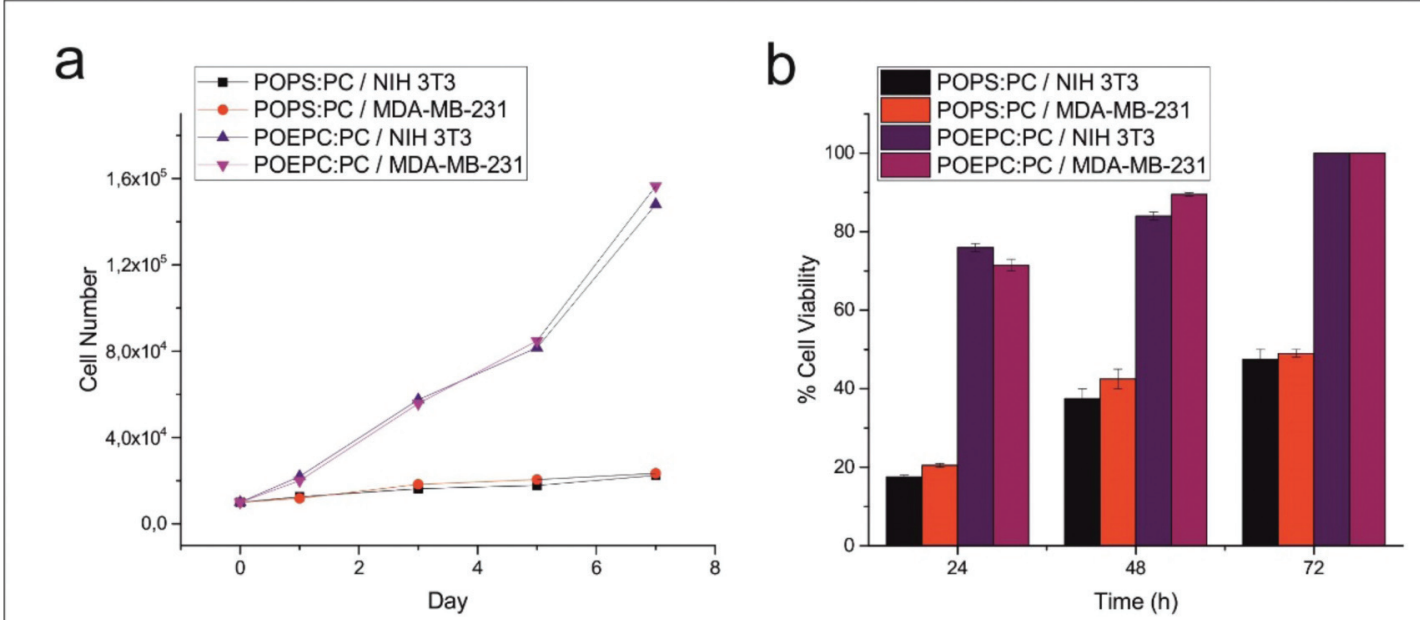

Figure 4. (a) Proliferation profiles of MDA-MB-231 and NIH 3T3 cells on POPS:PC and POEPC:PC functionalized solid surfaces for 7 days of culture time, (b) Cell viability analysis of MDA-MB-231 and NIH 3 T3 cells on POPS:PC and POEPC:PC functionalized solid surfaces for 72 hours.

event that takes place less than $100 \mathrm{~nm}$ distance. Here a surface sensitive evaluation technique; namely SPR, was utilized to investigate the cancer cell adhesion process onto charged lipid bilayers. SPR provides a real-time and a label-free evaluation for ionic interactions of cells with charged lipid surface in a close proximity. Real-time cell adhesion behaviours of MDA-MB-231 breast cancer cells and NIH 3T3 fibroblast cells (control group) were investigated for both POEPC:PC and POPS:PC functionalized bilayers (Fig 2c). Reflectivity of the surface changes through the cell adhesion onto charged lipid surfaces; in other words increasing reflectivity is explained as increasing interaction as well as cell adhesion. As shown in Figure 2, both cell lines showed high affinity to the POEPC:PC functionalized surfaces due to cationic nature of the surface. The reflectivity change was observed as $8.5 \%$ for MDA-MB-231 cell adhesion. However very low affinity and binding was observed, and the reflectivity change was less than $1 \%$ when negatively charged POPS:PC functionalized surfaces were utilized.

Cell adhesion and proliferation profiles were also investigated via microscopy imaging. As represented in Figure 3, microscopy images and area coverage data confirm that cell adhesion and proliferation was favoured and facilitated when the solid surface was functionalized with positively charged POEPC lipids. MDA-MB-231 and NIH 3T3 cells spread more over on positively charged POEPC lipid surfaces in 48 hours compared to negatively charged POPS lipid surfaces, where less cell attachment is observed (Figure 3). Surface coverage was more than $90 \%$ with POEPC:PC functionalized surfaces (Figures $3 a$ and $3 c$ ) while it was around $30-40 \%$ with POPS:PC functionalized bilayers (Figures $3 \mathrm{~b}$ and $3 \mathrm{~d}$ ).

\section{Cell Proliferation and Viability on Lipid Bilayer}

Surface: The viability of the cells on lipid functionalized surfaces and their proliferation behaviours were further checked on POEPC:PC and POPS:PC functionalized surfaces. At the end of 24 hour, when positively charged POEPC:PC was used cell viability and proliferation was higher than POPS:PC functionalized samples (Fig 4a). Cell proliferation was significantly increased for positively charged POEPC:PC lipid surfaces after 24 hours. Cell proliferation was triggered with the increasing cell adhesion when initial cellsurface contact is established successfully. However no significant proliferation ratio was observed for the negatively charged POPS:PC lipid surfaces, because of the limited interaction and repelling of negatively charged cell surface and surface lipids. 

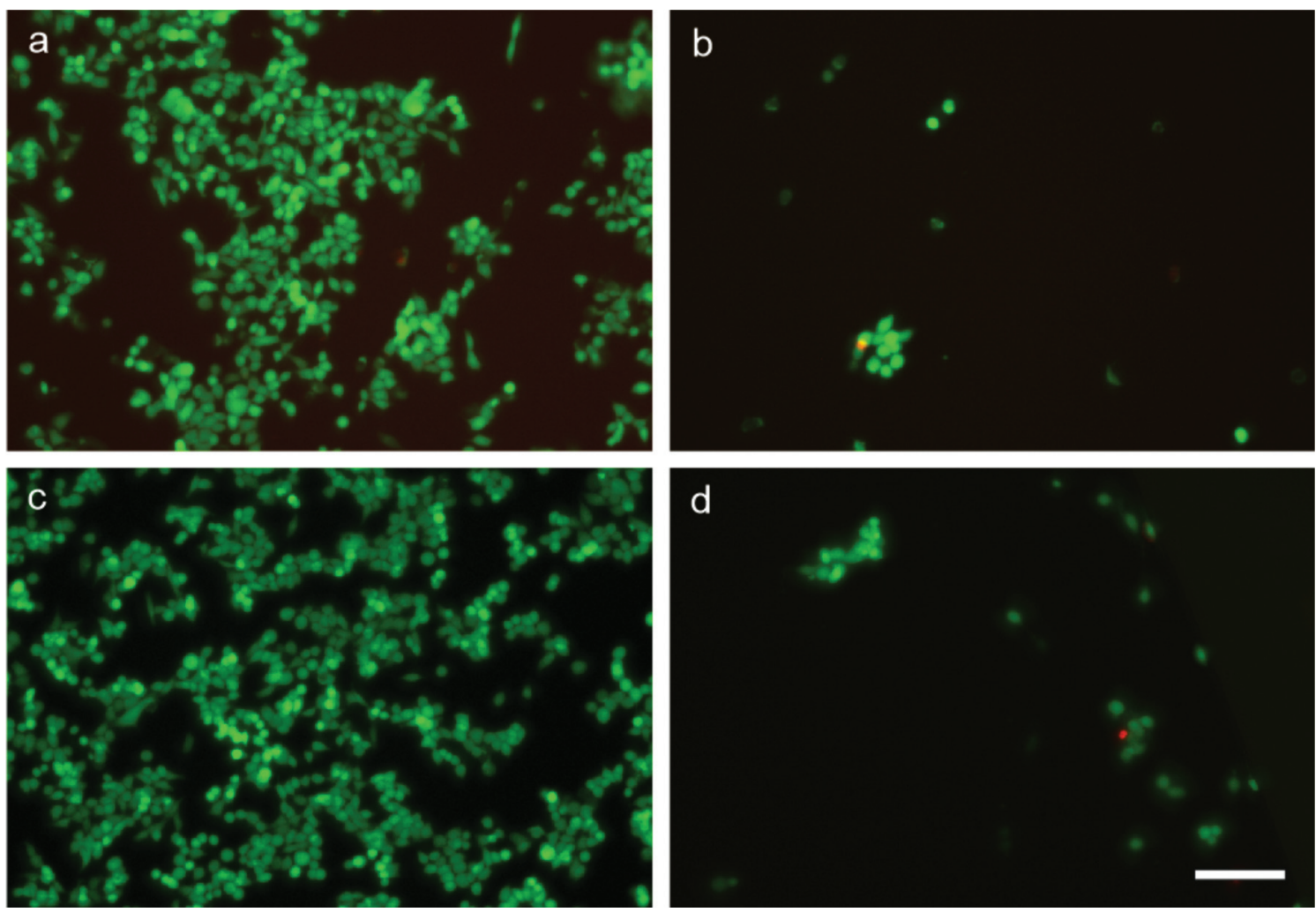

Figure 5. Live-dead assay of MDA-MB-231 cells on (a) POEPC:PC and (b) POPS:PC functionalized solid surface, and NIH 3T3 cells on (c) POEPC:PC and (d) POPS:PC functionalized solid surface. Live cells were represented by green colour while the dead cells were represented by red. (Scale bar $100 \mu \mathrm{m}$ ).

Further, the viability of adhered cells on either POEPC:PC or POPS:PC functionalized surfaces were evaluated both via alamar blue assay (Figure 4b) and live-dead assay (Figure 5). As expected the number of the live cells (Figure 5) and cell viability (Figure 4b) was higher for MDA-MB-231 cells when positively charged POEPC:PC lipid surface was used (Figure 5a). Cell viability was significantly reduced when POPS:PC lipid surface utilized (Fig 5b) indicating the unfavoured interaction of the cells and the surface.

\section{DISCUSSION}

Understanding the cancer cell-microenvironment interactions is essential hence it plays a vital role in new tumor formation process. Surface characteristics and lipid content of cell membrane have an important effect on the cell adhesion process. Cell adhesion to the surface begins with nonspecific interactions between cell and the surface. When cells reach to close proximity they start to adhere to the surface and become flattened. Cell adhesion occurs specifically through cell-membrane receptor interactions, while nonspecific interactions are mostly driven by ionic and hydrophilic interactions.

The main aim of this work was to investigate the interaction between charged lipid membrane surfaces and cell adhesion which might give clues about the mechanism of metastases. Herein, lipid membrane (tBLM) functionalized surfaces were utilized to investigate the cell-surface interactions and cancer cell adhesion profiles on lipid functionalized surfaces. First, the cell adhesion profiles of MDA-MB-231 breast cancer cells and NIH-3T3 fibroblast (control group) cells were investigated on negatively and positively charged lipid membrane surfaces by using SPR and microscopy; then cell proliferation and also viability was evaluated. As illustrated in Figure 1, surface charge highly affects the cell adhesion process. Positively charged tBLM surface favours the cell adhesion due to ionic interactions. 
This favoured electrostatic interaction was first confirmed by SPR data which indicated that there was a strong binding event observed for positively charged POEPC:PC functionalized surface while there is no binding for negatively charged POPS:PC functionalized surface. Additionally cell viability and proliferation results also assured that positively charged feature of POEPC:PC membrane structure creates better microenvironment for cells that triggers the cell adhesion when compared with negatively charged POPS:PC membrane.

\section{CONCLUSION}

Current study focuses on investigating the effect of surface properties and ionic interactions in cell adhesion process. Here cancer cell adhesion on charged tBLM surfaces has been demonstrated. Cell adhesion was significantly enhanced when positively charged POEPC:PC lipid surfaces were utilized. The cationic POEPC lipids facilitated the cell-lipid surface interactions through ionic forces that promote cell adhesion, spreading and proliferation. Based on these findings it can be concluded that developed lipid surface offers a promising platform for cell adhesion and cancer cell-based studies.

\section{Acknowledgement}

This work was supported by IYTE BAP; 2016 IYTE70. AAY would like to thank to Beste Elveren for her help on the manuscript.

Ethics Committee Approval: Not required.

Conflict of Interest: No conflict of interest.

Funding: IYTE BAP; 2016IYTE70

Informed Consent: Patient samples were not used in this work.

Etik Kurul Onayı: Etik kurul onayı gerekmemektedir.

Çıkar Çatışması: Çıkar çatışması bulunmamaktadır. Finansal Destek: IYTE BAP; 2016IYTE70

Hasta Onamı: Bu çalışmada hasta örneği kullanıımamıştır.

\section{REFERENCES}

1. van Dalum G, Holland L, WMM Terstappen L. Metastasis and Circulating Tumor Cells. Journal of the International Federation of Clinical Chemistry and Laboratory Medicine (JIFCC)2012. $11 \mathrm{p}$.

2. Abdel-Ghany $\mathrm{M}$, Cheng $\mathrm{H}-\mathrm{C}$, Elble RC, Pauli BU. The Breast Cancer $\beta 4$ Integrin and Endothelial Human CLCA2 Mediate Lung Metastasis. 2001;276(27):25438-46.

3. Felding-Habermann B, O'Toole TE, Smith JW, Fransvea E, Ruggeri ZM, Ginsberg $\mathrm{MH}$, et al. Integrin activation controls metastasis in human breast cancer. P Natl Acad Sci USA. 2001;98(4):1853-8. [CrossRef]

4. Wang H, Pilla F, Martinez-Escribano S, Bocca S, Oehninger S, Horcajadas JA. A Novel in Vitro Model of Human Implantation: An Endometrium-Like Three-Dimensional (3d) Culture System for Attachment/Invasion of Trophoblast-Like Cells. Fertil Steril. 2010;94(4):S64-S5. [CrossRef]

5. Andersson AS, Glasmastar K, Sutherland D, Lidberg U, Kasemo B. Cell adhesion on supported lipid bilayers. J Biomed Mater Res A. 2003;64a(4):622-9. [CrossRef]

6. Glasmästar K, Larsson C, Höök F, Kasemo B. Protein Adsorption on Supported Phospholipid Bilayers. Journal of Colloid and Interface Science. 2002;246(1):40-7. [CrossRef]

7. Kasemo B. Biological surface science. Surf Sci. 2002;500(1-3):656-77. [CrossRef]

8. Krishnan V, Kasuya Y, Ji Q, Sathish M, Shrestha LK, Ishihara S, et al. Vortex-Aligned Fullerene Nanowhiskers as a Scaffold for Orienting Cell Growth. Acs Appl Mater Inter. 2015;7(28):15667-73. [CrossRef]

9. Loessner D, Meinert C, Kaemmerer E, Martine LC, Yue K, Levett PA, et al. Functionalization, preparation and use of cell-laden gelatin methacryloyl-based hydrogels as modular tissue culture platforms. Nat Protoc. 2016;11(4):727-46. [CrossRef]

10. Pandian GN, Sugiyama H. Nature-Inspired Design of Smart Biomaterials Using the Chemical Biology of Nucleic Acids. B Chem Soc Jpn. 2016;89(8):843-68. [CrossRef]

11. Nawa $E$, Yamamoto D, Shioi A. Chemotactic Amoeboid-Like Shape Change of a Vesicle under a pH Gradient. B Chem Soc Jpn. 2015;88(11):1536-44. [CrossRef]

12. Biswas KH, Jackman JA, Park JH, Groves JT, Cho NJ. Interfacial Forces Dictate the Pathway of Phospholipid Vesicle Adsorption onto Silicon Dioxide Surfaces. Langmuir. 2018;34(4):1775-82. [CrossRef]

13. Ferhan AR, Jackman JA, Cho NJ. Investigating how vesicle size influences vesicle adsorption on titanium oxide: a competition between steric packing and shape deformation. Phys Chem Chem Phys. 2017;19(3):2131-9. [CrossRef]

14. Arslan Yildiz A, Yildiz UH, Liedberg B, Sinner E-K. Biomimetic membrane platform: Fabrication, characterization and applications. Colloids and Surfaces B: Biointerfaces. 2013;103:510-6. [CrossRef]

15. Satriano C, Svedhem S, Kasemo B. Well-defined lipid interfaces for protein adsorption studies. Phys Chem Chem Phys. 2012;14(48):16695-8. [CrossRef]

16. Schönherr H, Johnson JM, Lenz P, Frank CW, Boxer SG. Vesicle Adsorption and Lipid Bilayer Formation on Glass Studied by Atomic Force Microscopy. Langmuir. 2004;20(26):11600-6. [CrossRef]

17. Hirayama K, Akashi S, Furuya M, Fukuhara K-i. Rapid confirmation and revision of the primary structure of bovine serum albumin by ESIMS and frit-FAB LC/MS. Biochem Bioph Res Co. 1990;173(2):639-46. [CrossRef] 